\title{
Japan trips up over high-definition television
}

Tokyo. A top official of Japan's Ministry of Posts and Telecommunications has caused uproar by suggesting that Japan should follow the United States and Europe and switch to the development of digital high-definition television (HDTV), rather than the analogue version developed in Japan.

There has been little surprise at the proposal to move away from the analogue system, even though the Japan Broadcasting Corporation (NHK) and Japanese industry have invested billions of dollars in developing it over the past 30 years. But the way in which the suggestion was made - which has led to any move being postponed for a year - has thrown some revealing light on the limitations of Japan's 'consensus' style decision-making.

It is now widely recognized in Japanese industry that digital HDTV transmission systems developed primarily in the United States offer many advantages over NHK's analogue system.

These advantages will increase following the widespread efforts around the world to develop multimedia interactive television, combining conventional television and computer technology. Europe abandoned its analogue system and switched to the digital approach more than a year ago.

But when Akimasa Egawa, director-general of the telecommunications ministry's broadcasting administration bureau, revealed last week that his ministry planned to follow this worldwide trend, he received criticism from all sides.

Last week (22 February) the Nikkei Shimbun, Japan's leading financial daily newspaper, reported that Egawa had told a meeting of a section of the Shinseito party, one of the governing coalition parties, that "the world trend is towards digital systems and the analogue approach has failed". He also hinted that Japan's test broadcasts of analogue HDTV might be halted.

At a hurriedly called press conference, Egawa toned down his comments. But he confirmed that the ministry hopes to revise its policy on HDTV by the summer, and added that continuing to promote NHK's analogue system without acknowledging the worldwide shift to digital systems amounted to "cheating the public".

NHK immediately issued a press release describing Egawa's comments as "very regrettable". This was joined by a chorus of protests from both industry and the Ministry of International Trade and Industry. Tadahiro Sekimoto, chairman of the Electronic Industries Association of Japan, led the attack, and demanded the immediate withdrawal of Egawa's remarks.

(Ironically, Sekimoto is also president of NEC Corporation, whose researchers are furiously working on the development of digital systems, and his company probably stands in one of the best positions to take advantage of a digital standard.)

Egawa's biggest crime appears to be his failure to win the consensus of industry and NHK before making his remarks, even though his views are in tune with many in his ministry and in industry.

He called a second press conference the next day to assure his critics that the ministry would continue to support the analogue standard, at the same time as moving towards digital systems. But that was not enough, and the Minister of Posts and Telecommunications, Takenori Kanzaki, had to step in and announce that a decision on HDTV will be postponed for a year while an advisory committee discusses the issue.

Behind the uproar is Japan's massive investment in analogue HDTV. NHK began development work in 1964, and has invested close to $¥ 20$ billion (US\$200 million). Many electronics companies have in- vested similar amounts and some analysts place Japan's total investment at $¥ 1,000$ billion, although a more realistic figure is probably about half that amount.

NHK began experimental HDTV broadcasts of eight hours a day in 1991 and this will increase to 10 hours next month. But only about 20,000 HDTV sets have been sold, mainly because of their very high price - about $¥ 1$ million each - and the limited HDTV programming that NHK can offer. A full broadcasting schedule is due to start using a new satellite in 1997, and is planned to run for at least ten years.

Both NHK and Japan's electronics industry clearly hope to squeeze as much return as they can out of their investment. But if Japan tries to hang onto the analogue system while the rest of the world goes digital, it may well come under pressure from its competitors to open up its market to their digital systems.

\section{Protests greet plutonium promotion}

Tokyo. Attempts by the Japanese government to promote the use of plutonium in its nuclear power industry appear to have backfired. A promotional video made by the government-backed Power Reactor and Nuclear Fuel Corporation (PNC) to win public acceptance of plutonium has produced a storm of protest, including a request for its withdrawal from Hazel O'Leary, the US Secretary of Energy.

The video claims that it is safe for people to drink water contaminated with plutonium, and that there is no conclusive evidence that plutonium can cause cancer. But rather than reducing public opposition to the country's plutonium programme, the video seems likely to increase demands for the programme to be abandoned.

More than a hundred copies of the tenminute video were distributed last year by PNC in Fukui Prefecture, the location of Japan's prototype fast breeder reactor Monju, which is due to attain criticality in a few weeks. It features a cartoon character, Plutokun, who tries to dispel the public's fears and "misunderstandings" about plutonium.

The most controversial scene in the film shows a gang of bandits dumping a large can of plutonium into a reservoir. Pluto-kun reassures viewers that plutonium is hard to dissolve, and that most will sink to the bottom. He says that even if someone drinks water from the reservoir containing plutonium, most of it will pass through the stomach and intestine, and then be excreted. And Pluto-kun is shown shaking the hand of a young boy gulping down a large glass of plutonium-contaminated water (see photo).

In another scene, viewers are warned that

\section{IMAGE UNAVAILABLE FOR COPYRIGHT REASONS}

\section{"Drink up: it won't do you any harm"}

it is dangerous to inhale plutonium or let it enter the bloodstream because it lodges in the body for years. But Pluto-kun adds that "unlike radium, there is no proven case of plutonium in the body causing cancer".

Early in February, O'Leary - who is leading a campaign that has highlighted the US government's involvement in radiation experiments on humans in the $1960 \mathrm{~s}$ wrote to PNC urging the company to withdraw the video.

Satsuki Eda, the head of the Science and Technology Agency (to which PNC is affiliated), acknowledged last week that there are some "inappropriate" sequences in the video. "Plutonium must never be leaked into the environment and must never be drunk," he said. But Eda has declined to order PNC to withdraw the video, claiming that the "inappropriate" parts "do not detract from the video as a whole".

PNC officials say that, although they are prepared to listen to comments, they have no intention of withdrawing the video. They argue that it is intended to use non-academic terminology to show the public that plutonium is not as frightening as some critics maintain.
David Swinbanks 